\title{
A Paradoxically Significant Medicinal Plant Carapichea ipecacuanha: A Review
}

\author{
Sinjini Mondal, Saurav Moktan* \\ Department of Botany, University of Calcutta, Kolkata, West Bengal, INDIA.
}

\begin{abstract}
Background: Carapichea ipecacuanha (Brot.) L. Andersson is the botanical source of Ipecac drug and contains major alkaloids emetine, cephaline that are pharmaceutically used against bronchitis associated with cough in children, severe diarrhea (amoebic dysentery) and also cancer. Ipecac serves as an expectorant to thin mucous and easy coughing. Low doses are used to enhance appetite and it is administered orally to cause vomiting after suspected poisoning. Materials and Methods: The review highlights the taxonomy, nomenclature, distribution, medicinal uses and major pharmacological activities including side effects of Ipecac drug reported in recent years consulting various published papers dealing with Ipecac. Results and Conclusion: The species is rarely distributed due to disturbances in their habitats in natural growing condition. Further studies are required to scientifically evaluate the traditional uses of this plant through extraction and identification of their active ingredients and the mechanisms and mode of action that would serve as a source of collective information on this plant.
\end{abstract}

Key words: Carapichea ipecacuanha, Taxonomy, Distribution, Pharmacology, Medicine.

\section{INTRODUCTION}

Human beings are biological species existing in symbiotic relationships with a significant number of other biological species of plants and animals. We are dependent on biological diversity of plants and animals we consume and also raw materials and medicines that we use. ${ }^{1}$ Medicinal plants are considered as high yielding resources of ingredients that can be used in drug development either pharmacopoeial, nonpharmacopoeial or synthetic and thereby play a critical role in the development of human cultures and civilizations globally. ${ }^{2}$ The World Health Organization (WHO) defined Traditional Medicine as the sum total of all knowledge and practices, used in diagnosis, prevention and elimination of physical, mental, or social imbalance relying exclusively on practical experiences and observations translated from generation to generation. ${ }^{3}$ As per WHO, around 80 percent of people globally rely on herbal medicines for significant aspect of their primary health care. The "Green Wave" triggered by rising bionomical consciousness has given rise to increased involvement in herbal formulations all over the world. Consumption of medicinal plants has gone twice up in the western countries. The quantity of plant-derived medicaments or health foods has increased slowly to meet global demands. ${ }^{4}$ Around 21,000 plant species have the potential for being used as medicinal plants as per reports of WHO. ${ }^{5}$ Among ancient civilizations, India has been known to be rich repository of medicinal plants. Forests in India is the principal repository of numerous medicinal and aromatic plants, which are largely collected as raw materials for manufacture of drugs and other products. ${ }^{6}$ Approximately 8,000 herbal remedies have been databased in AYUSH systems. Ayurveda, Unani, Siddha and Folk medicines are the major systems out of which Ayurveda and Unani are most developed and widely practiced in
Submission Date: 07-08-2019; Revision Date: 26-09-2019; Accepted Date: 12-03-2020

DOI: 10.5530/ijper.54.2s.61 Correspondence: Dr. Saurav Moktan Department of Botany, University of Calcutta, 35, B.

C. Road, Kolkata-700 019, West Bengal, INDIA.

Phone: +917384336285 E-mail: sauravmkn@gmail. com

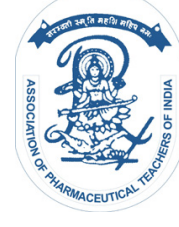

www.ijper.org 
India. ${ }^{7}$ Medicinal plants may gift three crucial benefits: health benefits to the people who consuming plants as medicines; monetary benefits to people who harvest, process and distribute them for commerce; and societywide benefits, creating job opportunities, tax revenues and a healthier labour force. ${ }^{8}$ Where medicinal plants are harvested from the wild rather instead of cultivation, they are exposed to both general and specific threats. General threats includes climate change and habitat loss to development and agriculture. A specific threat is overcollection to cope up with the demand for medicines. In Tropical regions, the practice of using plants against treatment of diseases is widespread and their importance and uses has been well documented ever since the old world met the native Americans. ${ }^{10}$ In Southern America, two of the important species, popularly known as cinchona (Cinchona spp. $)^{11}$ and ipecacuanha (Carapichea ipecacuanba (Brot.) L.Andersson) $)^{12}$ have been reported for treatment of various diseases and ailments. ${ }^{13}$ The species C. ipecacuanha is recognized one of the world's most important medicinal plants and Brazilian ipecac is considered the most valuable as it shows the highest emetine content. ${ }^{14}$

\section{Nomenclature}

Back in 1648 although Piso had referred the taxa $C$. ipecacuanba in Historia Naturalis Brasiliae, the notes were not fulfilling to be named legitimately. On the basis of material supplied by Joseph Celestine Mutis, a physician to the then Viceroy of New Granada, Linnaeus (1781) eventually described this material as Psychotria emetica L. f. in Supplementum Plantarum Systematis Vegetabilium. ${ }^{15}$ Félix Avellar Brotero of the University of Coimbra (Portugal) later in 1802 described this plant as Callicocca ipecacuanha. ${ }^{16}$ Persoon (1805), remembered best for his work on fungi, named this plant as Cephaelis ipecacuanha. ${ }^{17}$ The origin of the term ipecacuanha comes from the Brazilian Indians. ${ }^{18}$ The etymology comes from the Indian words ipe (bark), caa (plant), cua (fragnant), nha (grooved), i.e. "bark of fragnant and striated plant". ${ }^{19}$ Six synonyms have been designated for $P$. ipecacuanha, presently the common referred synonym is Cephaelis ipecacuanba. ${ }^{14}$ However, the most recent revised named as Carapichea ipecacuanha (Brot.) L. Andersson, which is actually accepted for the species. ${ }^{12}$

Cephaelis ipecacuanha was based on a collection by Bernardino Antonio Gomes in Brazil. ${ }^{20}$ The incorrectly given protologue, Bernard. Bnt. Gomes, led to the incorrect abbreviation B.B. Gomes and it was cited s.n. in LISU Herbaria (University of Lisbon) as holotype of Callicocca ipecacuanba. ${ }^{21}$ However, a precise study in LISU went futile and an excellent illustration of Gomes' material, present in the protologue, was therefore selected as lectotype. ${ }^{12}$

\section{Distribution}

C. ipecacuanha is native to forests of South and Cental America. ${ }^{22}$ It has a disjunctive distribution in rainforests of Central (Nicaragua, Costa Rica and Panama) and South America (Colombia and Brazil).The original inhabitants of the Brazilian territory already used ipecacuanha as medicine and were aware of its emetic properties. ${ }^{23}$ This indigenous knowledge was passed on to the European colonizers, who used the ipeca for decades as an emetic for patients who ingested poison and also for children who had ingested toxic substance. ${ }^{24}$ Carapichea is commonly known as Rio or Brazilian ipecac, indigenous to Brazil, particularly especially the moist and shady forests of Matto Grosso and Minas Geraes. ${ }^{25}$ It is also cultivated to some extent in Malaysia, Burma and the Darjeeling Hills of West Bengal, India. ${ }^{26}$ Ipecac in India was cultivated by the British in 1866 and 1872 from material sent from Brazil but proved to be unsuccessful. Over the years, limited production has been established at Malaya, Burma and Darjeeling district to Nilgiri and Sikkim in recent years. Ipecac has been produced along with companion crop Cinchona. The first written account about ipecacuanha can be traced back to 1601 by a Portuguese Jesuit who studied Brazilian history and recorded a drug named igpecaya or pigay. ${ }^{23}$ Ipecacuanha is a slow-growing plant and hence it has less economic appeal as a crop plant. It is rarely cultivated in South America but it has been cultivated in India to New Zealand. ${ }^{27}$

\section{Taxonomy}

Carapichea ipecacuanha (Brot.) L. Andersson is a species of plant belonging to the family Rubiaceae, one of the largest families of plants. This angiospermic family harbors around 13,000 species belonging to 650 genera $30 .{ }^{28}$ Ipecac plant cultivation is not easy outside its natural rainforest habitat, in southeast Asia several attempts have been made but was not of much success. ${ }^{29}$ In natural growth conditions, the plant species are distributed in circular as well as elliptically shaped clusters with very well delimited borders and occupy humid, shady areas under the forest canopy. ${ }^{30}$

Morphologically, the plant bears opposite leaves above, but usually naked below with pubescent toward the apex. Leaves are petiolate, entire, oblong, dark green with rough texture. Roots are branched and covered with a thick, transverse ringed bark, that becomes a diagnostic character for the drug. Colour shows reddish brown, with characteristic round ridges that are linked to 
subterranean stem by a ground distinct filament. At the base of leaf stalks, a pair of whitish stipules is seen. The inflorescence is capitate, enclosed by a large one-leafed involucres. Flowers are small, white, funnel-shaped, enclosed within four large ovate bracts, corolla white with reflexed limb segment, stamens 5, slightly exserted (Figure 4). The stamens and pistils are dimorphic with some flowers bearing long stamens and short pistils and in contrast, other flowers short stamens and long pistils. Fruit are berry, dark violet, crowned by the limb of the calyx, 2-celled, 2-seeded. ${ }^{31,32}$ Vernacular names Eng: Ipecac; Brazil: Rio ipecac. ${ }^{33}$ Other such popular names in Brazil include ipeca, poaia, poalba ${ }^{34}$ and pepaconba ${ }^{35}$ and also termed raicilla in Central America countries. ${ }^{36}$ Kannada: Ipikaakyunaoushadhi; Tamil: Ipika, ipikakku, ipikakkucceti; Urdu: Gurmarbuti. ${ }^{37}$

\section{Medicinal uses of Ipecac drug}

The importance of C. ipecacuanha in Historia Naturalis Brasiliae, probably, the oldest formal documentation of C. ipecacuanha use was highlighted. ${ }^{38}$ Roots of C. ipecacuanha were brought by Piso from Brazil to Europe in early 1649. However, the material was sceptically used by the Europeans until the early decades of the 1700s. Johann Schweitzer was the pioneer to use the material against dysentery suffered by Dauphin Louis, the eldest son of Louis XIV and Crown Prince of France. ${ }^{39}$ The roots were used especially against coughs, bronchitis, whooping cough and amoebic dysentery. The roots were usually harvested from 3 years old plants and dried. The plant is also used in homeopathy in the treatment of nausea. ${ }^{40}$ During World War I, approximately 4-7\% of the total number of patients admitted in military hospitals in North Africa suffered acute dysentery caused by Entamoeba histolytica, resulting in large number of casualties. ${ }^{41}$ By the year 1925, about $10 \%$ of the European and American population acquired E.histolytica cysts. ${ }^{42}$ Until 1960s, surgeons used root extracts of Carapichea to treat patients suffering from amoebic dysentery. An extensive study evaluating the utility of large doses of ipecacuanha by Joseph Ewart of the Bengal Medical Service has been published in the Indian Annals of Medical Science. ${ }^{43}$ Edward Scott Docker of the Indian Army Medical Service, while his stay in Mauritius, first tried large doses of ipecacuanha for treatment of dysentery in 1858 and succeeded in reducing patient mortality from 18 to $25 \% .{ }^{17}$ However, large doses of Ipecac through mouth were complicated by severe nausea and vomiting. Over the years, an alternative therapy was discovered by Leonard Rogers in India, that the principal alkaloid in ipecac killed amoebae in mucus of stools from patients with dysentery at dilution as high as 1/100000. In 1912, he successfully treated three patients in Calcutta,who had been unable to tolerate oral ipecac, by injection of emetine. ${ }^{44}$ In due course of time, surgeons in India used large doses of C. ipecacuanha root extracts. Dysentery was a prevalent disease and continues to be so within tropical country especially India. ${ }^{45}$ The World Health Organization (WHO) in compiling a global inventory of medicinal plants. It is an remarkable effort and if adopted by the Primary Health Care (PHC) as strategy, it could provide treatment of people worldwide, especially in the developing countries with comprehensive health care. Ipecac, or Syrup of Ipecac (SOI) is a drug used to induce vomiting and in higher doses it is a rapidly acting emetic. Excessive use of SOI as a purgative in eating disorders is increasing, even though its medicinal importance has lessened over the years. ${ }^{46}$ This drug was previously used as an expectorant in mild doses. Study was conducted to describe how "poaieiros" in Brazil maintained the cultural memory of $P$. ipecacuanha $a^{47}$ The root is the most utilized part and its mode of preparation is tincture or in mixture with tobacco, wine or sugarcane. The loss of knowledge associated with ipecac is caused by rural exodus, habitat due to deforestation and agricultural practices.

In the $19^{\text {th }}$ century, ipecacuanha was registered as an emetic and an expectorant in the pharmacies of Benedictine monasteries of Rio de Janeiro and Olinda, Brazil. ${ }^{48}$ For therapeutic uses and in treatment for dysentary, ipecac remained in India and Europe. ${ }^{49}$ The principal constituents in ipecac roots are emetine, a non-phenolic alkaloid and cephaeline, a phenolic alkaloid and the total content of the two alkaloids accounts for more than $84 \% .{ }^{50}$ Decoction of leaf is used as an expectorant and powdered form are used against dysentery. The alkaloids emetine and cephaline have proven pharmacologically active as emetics, antiamoebics and anti-diarrheal. ${ }^{51}$ Several uses of ipecac have been found in recent studies, including treatment against dysentery, bronchitis, worms, blood disorders, leukemia, teething children, cancer, induction of vomiting, expectorant and as an anti-amoebic. ${ }^{36} \mathrm{It}$ is also applied externally on the site of bites by the venomous insects and scorpions. ${ }^{52}$ Paradoxically, ipecac is itself a poison as it promptly induces vomiting. However, there is less concern for its intrinsically poisonous nature. ${ }^{46}$

\section{Recommended Dosage}

Ipecac syrup, consisting of total alkaloids 123 to $157 \mathrm{mg}$ per $100 \mathrm{~mL}$, has been administered to induce vomiting. Dosage range normally for the syrup is 10 to $30 \mathrm{~mL}$, yielding a dose of alkaloids of 12 to $48 \mathrm{mg}$. The syrup and fluid extract of ipecac have distinct properties, the 
extract is 14 times stronger than the syrup. Ipecac, is not recommended for routine use by the American Academy of Clinical Toxicology (AACT), the European Association of Poison Centres, Clinical Toxicologists (EAPCCT) and the American Academy of Pediatrics (AAP). ${ }^{53}$ However, for cumulative toxicity, for amoebic dysentery, administration of emetine in small doses for a short time span is given with intervals of some weeks then followed by further treatment. ${ }^{54}$ Ipecac is itself a poison as it readily induces vomiting. ${ }^{46}$ In human the most exhibited complication related to ipecac administration are diarrhea, lethargy, depression and prolonged vomiting. Therefore use of the emetic is not routinely recommended. ${ }^{55}$

\section{Production And Technology of Ipecac}

Ipecac cultivation is suitable in well-drained soil, rich in humus, with enough moisture, humidity and shade and it is difficult to cultivate outside natural habitat. During late spring season, propagation via green wood is usually done, in sandy soil compost at temperature around $21-24^{\circ} \mathrm{C}$. Ipecac can also be propagated via root cutting during seasons of harvesting. When the plants bear flowers, the roots are dug and then dried for use by the pharmaceutical industry. Cultivated plant are eventually replanted after partial removal of roots. The principal source of drug at present is Costa Rica.The global production of Ipecac is approximately 100 tonnes per year,which comes mostly from Nicaragua,Brazil and India. ${ }^{56}$ Cenargen initiated a program for the recollection and conservation of the genetic variability. During 1988 to 1991, five expeditions for collections were undertaken, in the States of Rondonia, MatoGrosso, Pernambuco, Bahia, Espirito Santo, Rio de Janeiro, Minas Gerais and 86 accessions were collected as well as maintained in field germplasm banks at EmbrapaOcidental Amazon, Belém, Para and at Florestas Rio doce, Linhares and Espirito Santo. ${ }^{34}$ In due course of time other germplasm collections was established at the University of North Fluminense. ${ }^{57}$ C. ipecacuanha species could be successfully regenerated by means of callus culture with 2,4-D and NAA along with kinetin promoting callus induction growth. ${ }^{58}$

The Brazilian medicinal species were challenged from intense extractivism (root harvesting and gradual loss of its habitat). A discussion to evaluate the three localization strategies of Mata Atalantica population and also to survey cultural and ethnobotanical aspects of the species was conducted. The species localization strategies were based on popular information-PL; Localization herbarium referred-HR and random localization-RL. ${ }^{59}$ Conservation and production of ipecac plants from long term shoot cultures have been established and due to high pharmacological value of emetine and high risk of extinction together with great market demand, a need for alternative cultivation methods is necessary. ${ }^{60}$ Data on the development of an in vitro root culture protocol for $P$. ipecacuanha. Leaf, nodal, intermodal rood segments were introduced in culture media containing different concentrations of Indol Butyric Acid (IBA). ${ }^{61}$

\section{Chemical Constituents}

In the year 1817, Pelletier and his group separated the "emetic principle" of ipecacuanha and named it as emetine. ${ }^{62}$ The active principle of ipecac was formed of many different bases. ${ }^{63}$ Firstly, the non-crystalline base which forms crystalline salts was emetine, the second one formed crystalline salts and was called cephaeline and another alkaloid was also identified as psycotrine. The constituents of the drug was mainly emetine (1-2\%), cephaeline, psychotrine, tannic acid called ipecacuanhic or cephaelic acid with starch, resin, etc. ${ }^{32}$ With the ratio of emetine to cephaeline content (i.e., 2-3:1), samples were indeed Cephaelis ipecacuanha and the standard current pharmaceutical substance was confirmed to be Cephaelis acuminata (with ratio emetine : cephaeline, 1:1). The active principles exist only in the bark of the root and probably in the thin, outer layer of cork cell. ${ }^{64}$ Alcohol extraction of the plants Cephaelis acuminata and Cephaelis ipecacuanha yield ipecac or Syrup of Ipecac (SOI). The extract is mainly a mixture with glycerin, sugar (syrup) and methyl paraben. The active ingredients are plant alkaloids, cephaeline and methylcephaeline (emetine). ${ }^{46}$

Gradually, emetine, $\mathrm{C}_{15} \mathrm{H}_{22} \mathrm{~N}_{2} \mathrm{O}_{5}$ and cephaeline, $\mathrm{C}_{14} \mathrm{H}_{20} \mathrm{NO}_{2}$, which were formerly supposed to be same were differentiated. ${ }^{65}$ The botanical source of Ipecac is cited in Pharmacopoeias as the dried roots of Carapichea ipecacuanba and Cephaelis acuminata. ${ }^{66}$ The roots of ipecac contain a number of medically active constituents including isoquinoline, alkaloids, tannins and glycosides. From the dried roots (crude drug "ipecac"), of $C$. ipecacuanha isolation of 6-O-methylipecoside, ipecosidic acid, neo-ipecoside, 7-O-methylneoipecoside, 3,4-dehydro neoipecoside and demethylalangi-side was done. ${ }^{67}$ Figure 1 represents the compounds isolated from roots of ipecac. ${ }^{68}$

Ipecacuanha obtained from C.ipecacuanha is a chemical compound with white crystalline bitter alkaloid, emetine named after its peculiar emetic principle. The chemical structure and stereochemistry of emetine were first studied and illustrated by chemical degradation experiments. ${ }^{69}$ Emetine was chemically characterized ${ }^{70}$ 

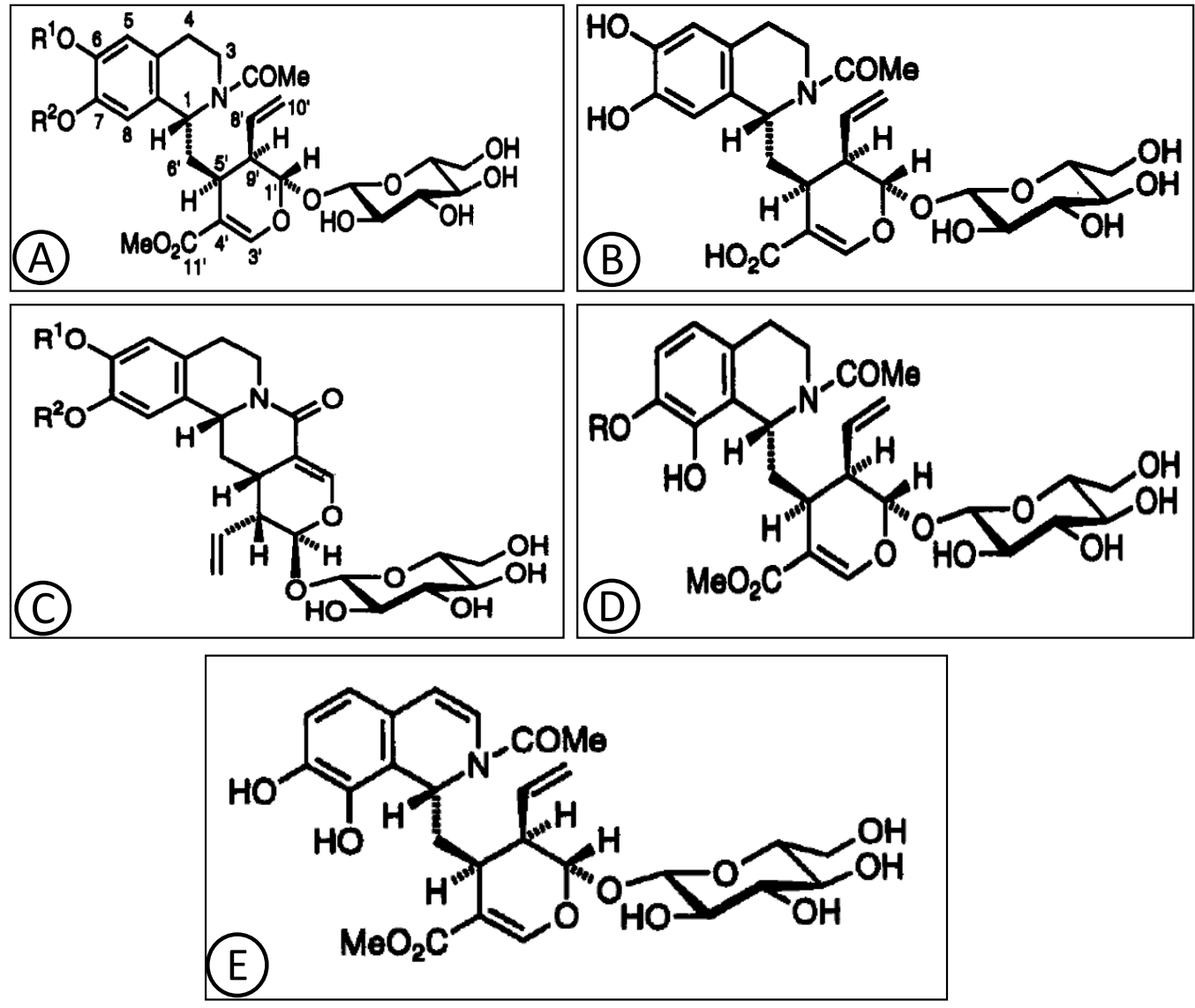

Figure 1: Chemical compounds isolated from roots of Ipecac; $A: 6-O$-Methylipecoside $R 1=M e, R^{2}=H$. B: Ipecosidic acid, C: Demetylalangiside $R^{1}=R^{2}=H$, D: Neoipecoside $R=H, 7-O$-Methylneoipecoside $R=$ Me. E: 3,4-dehydroneoipecoside.

and molecular structure of emetine was also provided as $\left(\mathrm{C}_{30} \mathrm{H}_{40} \mathrm{~N}_{2} \mathrm{O}_{5}\right)^{71}$ which remains valid today. ${ }^{65}$ The highest level of emetine is in the roots than in stems and leaves and none in the seeds of C. ipecacuanha. ${ }^{72}$ Emetine hydrochlorate have been obtained in crystalline form that became popular as a medicine. ${ }^{73}$ Figure 2 shows the chemical structure of emetine and cephaeline. ${ }^{74}$ Later, isolation and characterization of the other alkaloid cephaeline from C.ipecacuanha roots was also performed. ${ }^{6}$

\section{Biosynthesis of Emetine and Cephaeline}

The biosynthesis of emetine and cephaeline comes from two main biosynthetic pathways, the biosynthesis of dopamine from L-tyrosine and that of secologanin from geranyldiphosphate. ${ }^{75,76}$ Site of dopamine is cytosol, accumulated in the vacuole. The first step of the pathway is the condensation of dopamine and secologanin, two epimers, (S)-deacetylisoipecoside and the (R)-deacetylipecoside are formed as a result of condensation. The condensation reactions of dopamine and secologanin and of dopamine and protoemetine are supposed to occur in the vacuole. Then (S)-epimer is further converted to ipecac alkaloids such as cephaeline and emetine, the (R)-epimer gives rise to alkaloid alglucosides such as ipecoside and alangiside. Biosynthesis Emetine branches off from $\mathrm{N}$-deacetylisoipecoside through its 6-O-methylation by IpeOMT1, with assistance by IpeOMT2, further by deglucosylation by IpeGlu1. The 7-hydroxy group of the isoquinoline skeleton of the aglycon is methylated by IpeOMT3 before the formation of proemetine, followed by sequential O-methylations by IpeOMT2 and IpeOMT1 to form cephaeline and emetine, respectively. In addition to this central pathway of ipecac alkaloid biosynthesis, formation of all methyl derivatives of ipecac alkaloids could be explained by the enzymatic activities of IpeOMT1-IpeOMT3, exhibiting in Figure 3 that they are necessary for all O-methylation reactions of ipecac alkaloid biosynthesis. ${ }^{75}$ Biosynthesis of emetine and cephaeline ${ }^{77}$ and the ecology of variations in alkaloid production in C. ipecacuanba populations in widespread geographical regions have been since carried out. $^{78}$

\section{Uses of Emetine and Cephaeline}


<smiles>[R]c1cc2c(cc1OC)[C@H](C[C@H]1C[C@@H]3c4cc(OC)c(OC)cc4CCN3C[C@@H]1CC)NCC2</smiles>

Figure 2: Chemical structure of Emetine $\left(\mathrm{R}=\mathrm{OCH}_{3}\right)$ and Cephaline $(\mathrm{R}=\mathrm{OH})$.

Emetine is mainly used as an emetics to induce vomiting until the stomach turns empty, making it suitable for treating drug overdoses. Low doses acts as expectorant and excess dose leads to severe vomiting and diarrhoea. The gastric and bronchial systems are stimulated by emetine, curing fevers and cyst formation during amoebic dysentery. ${ }^{40}$ Emetine causes an increased secretion in the trachea in minute dose and therefore is recommended to clear throat. However, Cephaeline shows stronger emetic activity and higher toxicity. Emetine can kill protozoa, even at a concentration of $0.5-1.0 \mathrm{mg} / \mathrm{mL}$, therefore, it is used as a specific medicine targeted for treating amoebic dysentery. ${ }^{79}$

Emetine also exhibits cytotoxic activity, inhibiting protein synthesis, which makes it suitable for applications in drug-induced apoptosis. ${ }^{24}$ Emetine, has been found to have anti-helminthic and antiamoebic properties. ${ }^{46} \mathrm{In}$ recent times,synthetic analogues of emetine with less adverse effects are used in the treatment of amoebiasis. ${ }^{80}$

\section{Biological Activities of Emetine and Cephaline}

Investigations to determine the specific roles of emetine and cephaeline indicated that emetine was infact a 'good' expectorant, in comparison to cephaeline; however cephaeline was more efficient as an emetic. ${ }^{17}$

Anti cancer effect of emetine: An effective strategy implimented by scientists is the 'drug repositioning'. Emetine (EMT) have been shown to possess antitumor activity. ${ }^{81}$ The anti-cancer effect of EMT was first stated forward on malignant human tumors. ${ }^{82}$ In course of time, the review showed that EMT exhibits its anti-tumor effect. ${ }^{83}$ This was mainly by apoptosis regulation of pro-apoptotic factors. Mechanisms such as protein biosynthesis inhibition, DNA interaction, also causes the anti tumor effect. The EMT structure was derivatized at the $\mathrm{N}-2^{\prime}$ position then selectively delivered as a prodrug. An enzyme, fibroblast activation

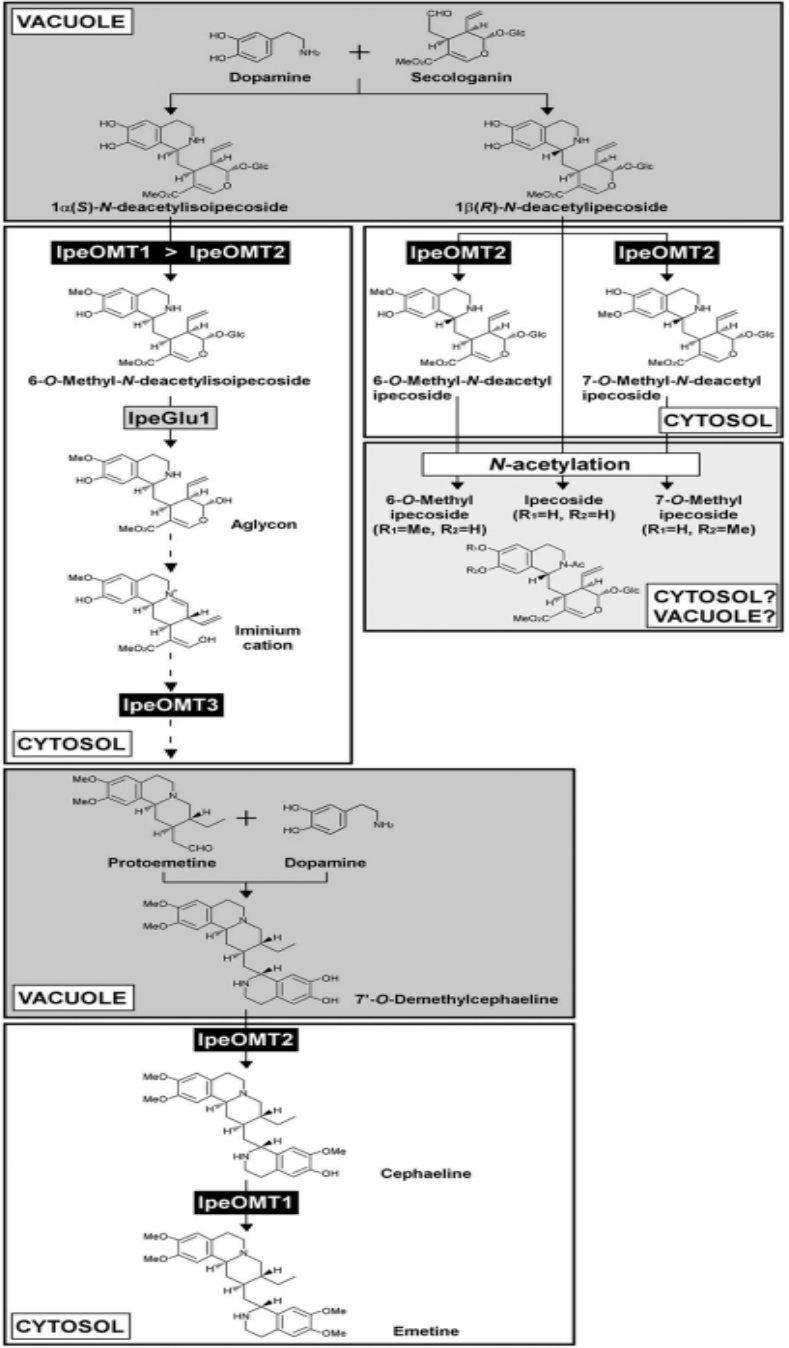

Figure 3: Biosynthetic pathway of Ipecac alkaloids highlighting major catalyzed reactions.

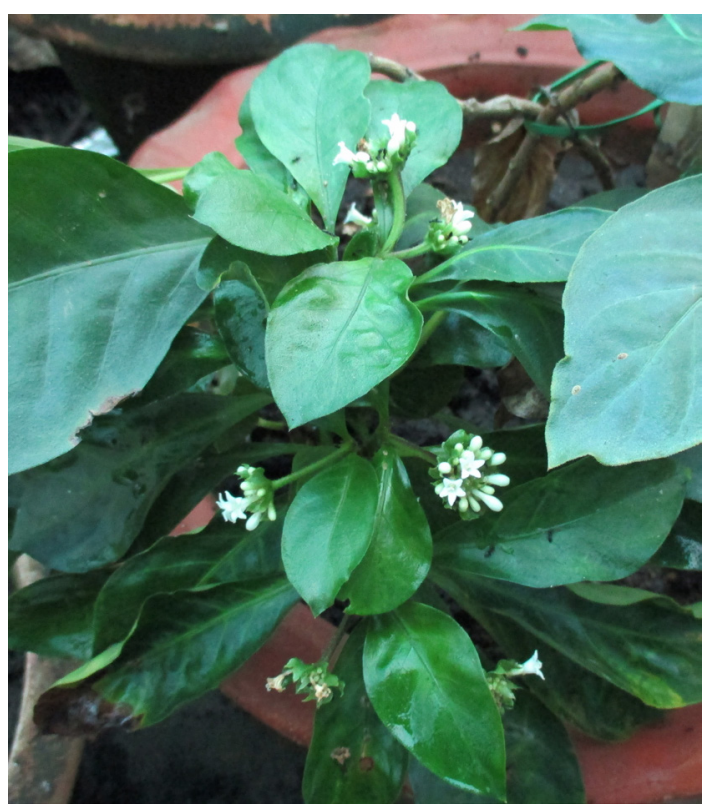

Figure 4: Carapichea ipecacuanha (whole plant). 
protein (FAP) which is overexpressed in certain cells within the metastatic tumor to cancer cells activates the prodrug. ${ }^{84}$ In case of Prostate PC 3 cells, cervical C33A cells, breast cancer MCF7 cells as well as MCF7/Adr cells, the alternative splicing of caspase 9 pre mRNA regulatory effects was carried out in response to EMT hydrochloride. It lead to the conclusion that the various splicing patterns of the caspase 9 gene were regulated by EMT and other compounds that acts by resisting or sensitizing the tumors to different cell death inducers. ${ }^{85}$ In Ovarian cancer, administration of cisplatin along with EMT was effective in inducing apoptosis. EMT affects the activation of caspases $-3,-7$ and -8 and downregulation of bcl-xL leading to apoptosis. ${ }^{86}$ EMT checks migration and invasion of human Non-SmallCell Lung Cancer (NSCLC) cells in cases of lung cancer. ${ }^{87}$

The results of investigations indicated, that Hedgehog (Hh) pathway is usually modulated by EMT and coristatin by binding to vital proteins in regulation of Cancer Stem Cells. ${ }^{88}$ Among the first compounds isolated, Emetine sensitizes the pancreatic tumor cells to Tumor Necrosis Factor-Related Apoptosis-Inducing Ligand (TRAIL)-induced apoptosis. ${ }^{50}$ Low nano molar concentrations of EMT completely inhibits expression of HIF $1 \alpha$ and HIF $2 \alpha$ that plays major role in hypoxia signaling and tumor growth progression. ${ }^{89}$

Protein, DNA, RNA synthesis inhibition: The inhibition of ribosomal protein synthesis in mammalian, yeast and plant cells by emetine with respect to concentration- and time-dependence was reported. ${ }^{90}$ Emetine also causes inhibiton of protein synthesis irreversibly in HeLa cells by lowering the number of free ribosomes and thereby increasing the polyribosomes. ${ }^{91}$ In Chinese Hamster Ovary (CHO) cells, the protein synthesis inhibition is reversible. ${ }^{92}$ The mechanism by which protein synthesis inhibition possibly occur are due to the inhibition of the aminoacyl RNA transfer reaction by emetine at $40 \mathrm{~S}$ ribosomal subunit site. ${ }^{93}$ In Exocrine cells and seminal vesicles of pancreas the emetine prevents induced autophagy by stabilizing polyribosomes and blocking of protein synthesis. ${ }^{94}$ Emetine has also been reported to inhibit DNA synthesis in sea urchin ${ }^{95}$ and mice. ${ }^{96}$ Emetine specifically targets and blocks the early $\mathrm{S}$ phase of DNA replication. ${ }^{97}$

The potential of this naturally occuring drug to inhibit protein synthesis was used in maintenance of the activity of alcohol dehydrogenase to reduce the pathological alcohol addiction. ${ }^{98}$

Antiparasitic property of emetine: Emetine has been widely utilised in the treatment of amoebiasis and amebic dysentery. The drug inhibits the growth of the causative agent Entamoeba histolytica. Emetine inhibits protein synthesis eventually kills the trophozoites of E. histolytica by irreversible and noncovalent binding to the peptide-chain elongation site of the $60 \mathrm{~S}$ subunit of ribosomes..$^{90}$ The effect of the drug has been verified as an effective anthelmintic effective against Protostron gylusrufescens in infected sheep and goat. ${ }^{99}$ It has been tried as trypanocidal agent against Trypanosoma cruzi $i$ in quest for drug against Chaga's disease. ${ }^{100}$ Emetine was effective at in vitro anti leishmanial activity against Leishmania donavani. ${ }^{101}$ Emetine by means of DNA intercalation and inhibition of protein biosynthesis could induce apoptosis in Trypanosoma brucei. ${ }^{102}$ Emetine and cephaline has potential for production of potent drugs against Leishmaniasis. ${ }^{103}$

Emetine an anti-protozoal agent, potently inhibits both ZIKV and EBOV entry in vitro and potent activity in vivo. Cephaeline, a desmethyl analog of emetine, also displays a similar efficacy against ZIKV as well as EBOV infections. ${ }^{104}$

Antiviral property of emetine: Emetine has some notable antiviral activities. Emetine was an able antipoxviral agent that blocked vaccinia virus replication at non-cytotoxic. ${ }^{105}$ This alkaloid compound was eventually reported to display antiviral activity against four serotypes of Dengue Virus (DENV) and a dosagedependent reduction of viral infection was observed at a noncytotoxic dose. ${ }^{106}$ Emetine inhibits HIV-1 replication by interfering with Reverse Transcriptase Activity. ${ }^{107}$

Infection with Human Cytomegalovirus (HCMV) is a threat for pregnant women and immunocompromised hosts but identification of emetine as HCMV inhibitor have been shown. ${ }^{108} \mathrm{HCMV}$ inhibition by emetine depended on ribosomal processing S14(RPS14) binding to MDM2, leading to disruption of MDM2-IE2 interactions.

Inhibition of the Nonsense mediated mRNA decay (NMD) Pathway: The mode of action used by cells to check the synthesis of truncated or defective protein is primarily via Nonsense-mediated decay (NMD). ${ }^{109}$ Emetine acts as an inhibitor to NMD. ${ }^{109}$ Emetine has been subsequently employed in GINI to inhibit NMD in prostate cancer cell lines (DU145, PC3 and LnCaP). ${ }^{110}$ Contraceptive property of Emetine: The potential of emetine as a protein synthesis inhibitor introduced the idea of determining its efficacy as a contraceptive agent when administered locally. ${ }^{111}$ An investigation was done in rabbit uterus and the results exhibited the anti implantation effect of emetine dihydrochloride, increased with the rise in concentration. ${ }^{111}$ Another study examined the suitability of emetine ditartrate as 
an emergency contraceptive. ${ }^{112}$ The uterus and early embryos around implantation, mainly the trophoblast and endometrial cells at the attachment site, are the primary target of the action of emetine ditartrate. Emetine ditartrate could be used to terminate human pregnancy in the initial stages. ${ }^{112}$

Toxic effects of emetine: Although emetine is an alkaloid of immense medicinal value. Its current medicinal use has been discouraged because of toxicity. Chronic usage has been reported to induce myopathy. ${ }^{113}$ Along with cardiotoxicity, cardiomyopathy as well is an adverse chronic use of emetine. ${ }^{114}$ In an experiment performed on protein pharmacology to ligand chemistry, various other targets were discovered for emetine and these lead to some of the side effects of the pharmacological use. ${ }^{115}$

\section{Mechanism and Mode of Action}

The major alkaloids of ipecac (emetine and cephaeline) are apparently pharmacologically active and have both local and central activity. Locally causing an irritant effect on gastric mucosa, whereas the central activity leads to the stimulation of the chemoreceptor trigger zone. While occurrence of vomiting, contents from both the stomach and small intestine are expelled. ${ }^{116}$ Patients who are hypoxic, dyspneic, not able to swallow, hypovolemic or comatose the effect of emetics are contradicted. Emetics should not be given after ingestion of petrolatum or similar chemical compounds as the chance of subsequent aspiration out competes the potential toxicity. Overdose of ipecac usually leads to cardiotoxicity. In the presence of strychnine intoxication, or with other CNS stimulants, use of emetics might precipitate seizures. ${ }^{116}$ Adsorption of ipecac syrup by activated charcoal may occur, therefore these drugs should not be administered simultaneously. In such cases, ipecac syrup should be given first and then administration of activated charcoal only once if vomiting has occurred. The effectiveness of ipecac may be decreased by consumption of dairy products and carbonated beverages. Biologically active emetine, $\mathrm{C}-1^{\prime}$ have the $\mathrm{R}$ configuration and the $2^{\prime}$ position have a secondary amine..$^{0}$ The epimer, 2 (isoemetine) with the $\mathrm{S}$ configuration at $\mathrm{C}-1^{\prime}$ is inactive. The activity was absent in case of 3 (O methylpsychotrine) with unsaturation at the $1^{\prime}-2^{\prime}$ positions and 4 (N-methylemetine) indicating that the position must be a secondary amine. The unsaturation at the $2-3$ positions to give 5 (dehydroemetine) and the asymmetry is lost at carbons 2 and 3 but this change does not affect protein synthesis inhibition. The tertiary nitrogen is converted into a quaternary ammonium moiety by oxidation to 6
$(1,2,3,4,5,11 \mathrm{~b}$ trisdehydroemetine) which results in loss of activity. In course of time, results obtained confirmed the $\mathrm{R}$ configuration at the $\mathrm{C}-1^{\prime}$ position and methoxy group at C- $7^{\prime}$ is a necessary structural requirement for the biological activities of emetine. C- $7^{\prime} .{ }^{117}$

\section{CONCLUSION}

The aim of this review was to showcase the valuable applications of plant species Carapichea ipecacuanha, its unique emetic properties and various compounds. Due to its potential toxicity and effect of overdose, ipecac syrup is not recommended. However, chemical compounds such as emetine, cephaline extracted from the plant has multiple function in treating various ailments. Thus, it is important to get familiar with the plant species from a medicinal perspective. The policy makers and health administrators should encourage research works based on medicinal plants that are given utmost priorities. ${ }^{118}$ Plant-derived pharmaceuticals are fast growing and becoming the major commercial development in biotechnological industry. They also provide the futuristic opportunity to provide low-cost pharmaceuticals to the developing nations. ${ }^{119}$ The recent researches conducted on herbal plants or medicine, have been a significant achievements in the pharmacological evaluation of various plants used for long in traditional systems of medicine. Therefore, plants can be a major source of medicines due to availability of its active compounds that can be added and prescribed through standardized dosages as crude or processed drugs for the betterment of humankind.

\section{ACKNOWLEDGEMENT}

The authors wish to thank the Department of Botany, University of Calcutta for all the necessary help required in writing this manuscript.

\section{CONFLICT OF INTEREST}

The authors declare that they have no conflict of interest.

\section{ABBREVIATIONS}

WHO: World Health Organization; AYUSH: Ayurveda, Yoga and Naturopathy, Unani, Siddha and Homoeopathy; PHC: Primary Health Care; SOI: Surup of Ipecac; AACT: Academy of Clinical Toxicology; EAPCCT: European Association of Poison Centre, Clinical Toxicologists; AAP: Americam Academy of Pediatrics; NAA: Napthalene Acetic Acid; IBA: Indole 
Butyric Acid; EMT: Emetine; NSCLC: Non-small Cell Lung Cancer; TRAIL: Tumor Necrosis Factor Related Apoptosis Inducing Ligand; DNA: Deoxyribonucleic Acid; RNA: Ribonucleic Acid; ZIKV: Zika Virus; EBOV: Ebola Virus; DENV: Dengue Virus; HIV: Human Immuno Virus; HCMV: Human Cytomegalo Virus; NMD: Non-sense Mediated mRNA decay; CNS: Central Nervous System.

\section{REFERENCES}

1. Octavian S, Ksenzhek A, Volkov G. Humans and Plants. Plant Energetics, Academic Press. 1998;335-45.

2. Kittredge J. The Importance of Herb. Northeast Organic Farming Association, (NOFA), www.nofa.org, 411 Sheldon Rd., Barre. 2012. MA 01005, 978-3552853.

3. World Health Organization. Alma-Ata Primary Health Care. World Health Organization. Geneva. 1978.

4. Grabley S, Sattler I. Natural products for lead identification: Nature is a valuable resource for providing tools. In Modern methods of drug discovery. Birkhauser, Basel. 2003;87-107.

5. Joy PP, Thomas J, Mathew S, Skaria BP. Medicinal Plants. Trop Hort: Naya Prokash, Calcutta. 2001;449-632.

6. Bhat ZA. Traditional medicines in drug discovery. J Pharm Res. 2015;(5):2457-9.

7. Ravishankar B, Shukla VJ. Indian systems of medicine: a brief profile. African J Traditional, Comple Alt Med. 2007;4(3):319-37.

8. Smith-Hall C, Larsen HO, Pouliot M. People, plants and health: A conceptual framework for assessing changes in medicinal plant consumption. J Ethnobiol and Ethnomed. 2012;8(1):43

9. Kling J. Protecting medicine's wild pharmacy. Nature Plants. 2016;2(5):16064.

10. Crespo $f$. The cinchona before and after the viceroyalty of the chinchon, count. Interciencia.1994;19(3):130-6.

11. Kurian A, Sankar MA. Medicinal plants. New India Publishing. 2007.

12. de Boer HJ, Thulin M. Lectotypification of Callicocca ipecacuanha Brot. and neotypification of Cephaelis acuminata $\mathrm{H}$. Karst., with reference to the drug ipecac. Taxon. 2005;54(4):1080-2.

13. Medeiros MF, Andreata RH, Valle LD. Identificaçao de termos oitocentistas relacionados às plantas medicinais usadas no Mosteiro de São Bento do Rio de Janeiro, Brasil. Acta Botanica Brasilica. 2010;24(3):780-9.

14. Assis MC, Giulietti AM. Morphological and anatomical differentiation in populations of "ipecacuanha" - Psychotria ipecacuanha (Brot.) Stokes (Rubiaceae). Rev Brasil Bot. 1999;22(2):205-16.

15. Smith JE. A Selection of the Correspondence of Linnaeus and Other Naturalists from the Original Manuscripts, Longman, Hurst, Rees, Orme and Brown, 580. London. 1821;2.

16. Persoon CH. Synopsis Plantarum, Seu Enchiridium Botanicum Complectens Enumeration em Systematicam Specierum Hucusque Cognitarum (Part I), C. F. Cramer, Paris Lutetiorum and J. G. Cottam, Tubingen. 1805;546.

17. Raman R, Raman A. Amoebic Dysentery and Introduction of Emetine Source Carapichea ipecacuanha into Indian Subcontinent. Indian J Hist Sci. 2017;52(1):54-65.

18. Sandwith FM, Durh MD, Lond FRCP. The lettsomian lectures on dysentery. The Lancet. 2014;184(4749):731-6.

19. Saint-Hilaire A. Plantas usuais dos brasilieiros. BeloHorizonte: Codigo Comunicacao. 2009.

20. Brotero A. Descr. of Callicocca Ipecacuanha in transact. of Linn, soc. 1802.

21. Andersson L. Re-establishment of Carapichea (Rubiaceae, Psychotrieae). Kew Bulletin. 2002;57(2):363-74.

22. Nomura T, Quesada AL, Kutchan TM. The new $\beta$-D-glucosidase in terpenoidisoquinoline alkaloid biosynthesis in Psychotria ipecacuanha. J Biol Chem. 2008;283(50):34650-9

23. Lorenzi H, Matos FJ. Plantas medicinais no Brasil: nativas e exóticas. 2002.
24. Moller M, Herzer K, Wenger T, Herr I, Wink M. The alkaloid emetine as a promising agent for the induction and enhancement of drug-induced apoptosis in leukemia cells. Oncology Reports. 2007;18(3):737-44.

25. Bajaj YP. Biotechnology in agriculture and forestry 21: Medicinal and Aromatic Plants IV. Springer-Verlag. 1993.

26. Trease GE, Evans WC. Pharmacognosy. $11^{\text {th }}$ Edn., Macmillan Publishers, London, UK. 1989.

27. Wapf V. The Disease of Chopin.Comprehensive study of a lifelong suffering. Litres, Russia. 2018.

28. Bremer B, Eriksson T. Time tree of Rubiaceae: Phylogeny and dating the family, subfamilies and tribes. Int J PI Sci. 2009;170(6):766-93.

29. Bown D. The Royal Horticultural Society encyclopedia of herbs and their uses. Dorling Kindersley Limited. 1995.

30. DeOliveira L, Martins ER. A quantitative assessment of genetic erosion in ipecac (Psychotria ipecacuanha). Genetic Res Crop Evol. 2002;49(6):60717 .

31. Lloyd JU. Cephaelis Ipecacuanha. The Western Druggist. 1897;346.

32. Sayre LE. A Manual of Organic Materia Medica and Pharmacognosy: An Introduction to the Study of the Vegetable Kingdom and the Vegetable and Animal Drugs (with Syllabus of Inorganic Remedial Agents) Comprising the Botanical and Physical Characteristics, Source, Constituents, Pharmacopoeial Preparations, Insects Injurious to Drugs and Pharmacal Bot. Blakiston. 1917.

33. Felter HW. The Eclectic Materia Medica Pharmacol and Therap cincinnati. John K Scudder, Ohio. 1922.

34. Skorupa LA, Assis MC. Collection and conserving Ipecae (Psychotria ipecacuanha, Rubiaceae) germplasm in Brazil. Economic Bot. 1998;52(2):209-10.

35. Souza MM, Martins ER, Pereira TN, Oliveira LO. Reproductive studies in Ipecac (Psychotria ipecacuanha (Brot.) Stockes; Rubiaceae): Pollen development and morphology. Brazilian Arch Biol Tech. 2008;51(5):981-9.

36. DeAlbuquerque UP, Monteiro JM, Ramos MA, DeAmorim EL. Medicinal and magic plants from a public market in northeastern Brazil. J Ethnopharmacol. 2007;110(1):76-91.

37. Ved DK, Sureshchandra ST, Barve V, Srinivas V, Sangeetha S, Ravikumar K, et al. FRLHT's ENVIS Centre on Medicinal Plants, Bangalore. 2016.

38. Piso W. Historia Naturalis Brasiliae, Ludvicum Elzevirium (later Elsevier), Amsterdam. 1648;293.

39. Thomson AT. The London Dispensatory: A Practical Synopsis of Materia Medica, Pharmacy and Therapeutics, Longman, Rees, Orme, Brown and Green, London.1826;1071.

40. Criddle LM. An overview of pediatric poisonings. AACN Advanced Critical Care. 2007;18(2):109.

41. Woodcock HM. Protozoological Experiences during the Summer and Autumn of 1916. J Royal Army Medical Corps. 1917;29(3):290-300.

42. Brug SL. Zur Epidemiologie der Amöbendysenterie. Archiv für Schiffs-und Tropen Hygiene. 1925;29:26-31.

43. Fayrer J. Tropical Dysentery and Chronic Diarrhea. Liver Abscess-Malarial Cachexia-Insolation with Other Forms of Tropical Disease and on Health of European Children and Others in India. 1881;118-71.

44. Rogers $\mathrm{L}$. The rapid cure of amoebic dysentery and hepatitis by hypodermic injections of soluble salts of emetine. Brit Med J. 1912;1(2686):1424.

45. Peterson KM, Singh U, JrPetri WA. 'Enteric Amebiasis' Tropical Infectious Diseases: Principles, Pathogens and Practice, Saunders Elsevier, Philadelphia. 2011;614.

46. Benzoni T, Gibson JG. Ipecac. In: Stat Pearls: Treasure Island (FL): StatPearls Publishing, Germany. 2019. [Updated 2019 Aug 13].

47. Teixeira VA, Coelho MF, Ming LC. Ipecac [Psychotria ipecacuanha (Brot.) Stoves]: aspects of cultural memory of" poaieiros" in Cáceres-Mato Grosso, Brazil. Revista Brasileira De Plantas Medicinais. 2012;14(2):335-43.

48. Medeiros MF, DeAlbuquerque UP. The pharmacy of the Benedictine monks: The use of medicinal plants in Northeast Brazil during the nineteenth century (1823-1829). J Ethnopharmacol. 2012;139(1):280-6.

49. Junior WS, Cruz MP, DosSantos LL, Medeiros MF. Use and importance of quina (Cinchona spp.) and ipeca (Carapichea ipecacuanha (Brot.) L. Andersson): Plants for medicinal use from the $16^{\text {th }}$ century to the present. $J$ Herb Med. 2012;2(4):103-12. 
50. Han Y, Park S, Kinyua AW, Andera L, Kim KW, Kim I. Emetine enhances the tumor necrosis factor-related apoptosis-inducing ligand-induced apoptosis of pancreatic cancer cells by downregulation of myeloid cell leukemia sequence-1 protein. Oncology Reports. 2014;31(1):456-2.

51. Brandão MG, Zanetti NN, Oliveira P, Grael CF, Santos AC, Monte-Mór RL. Brazilian medicinal plants described by $19^{\text {th }}$ century European naturalists and in the Official Pharmacopoeia. J Ethnopharmacol. 2008;120(2):141-8.

52. Singh S. Ethnobotanical study of wild plants of parsa district, nepal. Ecoprint: An Inter J Ecol. 2017;24:1-2.

53. Curtis RA, Barone J, Giacona N. Efficacy of ipecac and activated charcoal/ cathartic: Prevention of salicylate absorption in a simulated overdose. Arch Intern Med. 1984;144(1):48-2.

54. Minton N, Swift R, Lawlor C, Mant T, Henry J. Ipecacuanha-induced emesis: A human model for testing antiemetic drug activity. Clinical Pharmacol Therap. 1993;54(1):53-7.

55. Hojer J, Troutman WG, Hoppu K, Erdman A, Benson BE, Mégarbane B, et al. Position paper update: Ipecac syrup for gastrointestinal decontamination. Clinical Toxicology. 2013;51(3):134-9.

56. Mangathayaru K. Pharmacognosy: An Indian perspective. Pearson Education India. 2013;98.

57. Vieira RF. Conservation of medicinal and aromatic plants in Brazil. Perspectives on New Crops and New Uses. 1999;152.

58. Rout GR, Samantaray S, Das P. In vitro somatic embryogenesis from callus cultures of Cephaelis ipecacuanha A. Richard. Scientia Horticulturae. 2000;86(1):71-9.

59. Martins ER, Oliveira L. Conservation of ipecac (Psychotria ipecacuanha Standl): I - Localization strategies of populations and ethnobotany. Revista Brasileira De Plantas Medicinais. 2005;7:6-10.

60. Chaudhuri RK, Jha TB. Conservation and production of Ipecac (Cephaelis ipecacuanha Rich.) plants from long term shoot cultures. PI Tissue Cult Biotech. 2008;18(2):157-64.

61. Silva S, Filho A. Effect of indolebutyric acid on in vitro root production of Psychotria ipecacuanha (Brot.) Stokes (Rubiaceae). Revista Fitos. 2018;(12):218-26.

62. Sandwith FM, Durh MD, Lond FRCP. The lettsomian lectures on dysentery. The Lancet. 2014;(184):731-6.

63. Paul BH, Cownley AJ. Chemistry of ipecacuanha. Pharma J. 1894;(25):111-5, 373-74, 690-92.

64. Kraus L, Carstens J, Richter R. HPLC determination of emetine and cephaeline in ipecacuanha. Dtsch Apoth Ztg. 1985;125:863

65. Craig CR, Stitzel RE. Modern Pharmacology wit Clinical Applications, Lippincott Williams and Wilkins (now Wolters Kluwer), Philadelphia. 2004;824.

66. Bruneton J. Pharmacognosy, phytochemistry, medicinal plants. Lavoisier Publishing. 1995.

67. Itoh A, Ikuta Y, Tanahashi T, Nagakura N. Two Alangium alkaloids from Alangium I amarckii. J Nat Prod. 2000;63(5):723-5.

68. Fujii T, Ohba M. The alkaloids:chemistry and biology. Academic Press: San Diego. 1998;51:271.

69. Battersby AR, Openshaw HT, Wood HC. The constitution of emetine. Experientia. 1949;5(3):114-5.

70. Magendie F, Pelletier PJ. 'Rechercheschimiques et physiologiquessurl' ipécacuanha'. Annales De Chimieet Physique. 1817;4:172-85.

71. Simonson W. Emetine valuation of fluid extract of ipecac. Am J Pharm. 1890;62:532.

72. Hooper D. The value of the unofficial parts of ipecacuanha. Am J Pharm (1835-1907). 1892;162.

73. Flückiger FA. Pharmacognasie des Pflanzenreiches, R. Gaertner's Verlagsbuchhandlung, Berlin. 1891;1117.

74. Han GR, Wang YF, Feng SH, Jia YX. Simultaneous determination of cephaeline and emetine in ipecac and its preparations using RP-HPLC. Chinese Herb Med. 2013;5(4):286-91.

75. Nomura T, Kutchan TM. Is a metabolic enzyme complex involved in the efficient and accurate control of Ipecac alkaloid biosynthesis in Psychotria ipecacuanha?. Plant Signaling and Behavior. 2010;5(7):875-7.

76. Cheong BE, Takemura T, Yoshimatsu K, Sato F. Molecular cloning of an O-methyltransferase from adventitious roots of Carapichea ipecacuanha. Biosc, Biotech, Biochem. 2011;75(1):107-13.
77. Asano T, Kushida H, Sadakane C, Ishihara K, Wakui Y, Yanagisawa T, et al. Metabolism of ipecac alkaloids cephaeline and emetine by human hepatic microsomal cytochrome P450s and their inhibitory effects on P450 enzyme activities. Biol Pharm Bull. 2001;24(6):678-82.

78. Garcia RM, DeOliveira LO, Moreira MA, Barros WS. Variation in emetine and cephaeline contents in roots of wild Ipecac (Psychotria ipecacuanha). Biochem Systematics Ecol. 2005;33(3):233-43.

79. Funayama S, Geoffrey A, Cordell GA. Alkaloids Derived from Phenylalanine and Tyrosine, Alkaloids. Academic Press. 2015;21-61.

80. Magana-Garcia M, Arista-Viveros A. Cutaneous amebiasis in children. Pedia Dermatol. 2008;10:352-5.

81. Uzor PF. Recent developments on potential new applications of emetine as anti-cancer agent. EXCLI J. 2016;15:323-8.

82. Lewisohn R. Action of emetine on malignant tumors. J Am Med Assoc. 1918;70:9-10.

83. Akinboye SE, Bakare O. Biological activities of emetine. The Open Nat Prod J. 2011;4(1).

84. Foreman KE, Patel D, Davidson V, Kuo P, Flanigan R, Gupta GN. MP45-09 emetine dihydrochloride preferentially inhibits Hif1 $\alpha$ and Hif2 $\alpha$ expression in bladder cancer cells. J Urol. 2015;193:e538-9.

85. Pan D, Boon-Unge K, Govitrapong P, Zhou J. Emetine regulates the alternative splicing of caspase 9 in tumor cells. Oncology Letters. 2011;2(6):1309-12.

86. Sun Q, Yogosawa S, lizumi Y, Sakai T, Sowa Y. The alkaloid emetine sensitizes ovarian carcinoma cells to cisplatin through downregulation of bclXL. Int J Oncol. 2015;46(1):389-94.

87. Kim JH, Cho EB, Lee J, Jung O, Ryu BJ, Kim SH, et al. Emetine inhibits migration and invasion of human non-small-cell lung cancer cells via regulation of ERK and p38 signaling pathways. Chemico-biol Interactions. 2015;242:25-33.

88. Jaitak V. Molecular docking study of natural alkaloids as multi-targeted hedgehog pathway inhibitors in cancer stem cell therapy. Comput Biol Chem. 2016;62:145-54.

89. Foreman K, Jesse J, Gupta G. Emetine dihydrochloride: A novel therapy for bladder urothelial carcinoma. The J Urology. 2013;189(4S):e245-599.

90. Grollman AP. Structural basis for inhibition of protein synthesis by emetine and cycloheximide based on an analogy between ipecacalkaloids and glutarimide antibiotics. Proc Natl Acad Sci USA. 1966;56(6):1867-74.

91. Grollman AP. Inhibitors of protein biosynthesis V. Effects of emetine on protein and nucleic acid biosynthesis in HeLa cells. J Biol Chem. 1968;243(15):408994.

92. Gupta RS, Krepinsky JJ, Siminovitch L. Structural determinants responsible for the biological activity of (-)-emetine,(-)-cryptopleurine and (-)-tylocrebrine: Structure-activity relationship among related compounds. Mol Pharmacol. 1980;18(1):136-43.

93. Jimenez A, Carrasco L, Vazquez D. Enzymic and nonenzymic translocation by yeast polysomes. Site of action of a number of inhibitors. Biochemistry. 1977;16(21):4727-30.

94. Kovacs J, Rez G. Prevention of induced autophagy by emetine in exocrine cells of mouse pancreas and seminal vesicle. Virchows Archiv B. 1974;15(1):209.

95. Watanabe N, Shimada $\mathrm{H}$. Effects of emetine on initiation of DNA synthesis in embryonic cells of sea urchin. Cell Differentiation. 1983;13(3):239-45.

96. Antoni F, Luat NN, Csuka I, Olah I, Sooki-Toth A, Bánflavi G. The immunosuppressive effect of acute doses of emetine on murine thymic cells. Int J Immunopharmacol. 1987;9(3):333-40.

97. Schweighoffer T, Schweighoffer E, Apati A, Antoni F, Molnar G, Lapis K, et al. Cytometric analysis of DNA replication inhibited by emetime and cyclosporin A. Histochemistry. 1991;96(1):93-7.

98. Nikolaenko VN. Maintenance of Homeostasis of Endogenous Ethanol as a Method for the Therapy of Alcoholism. Bull Experi Biol Med. 2001;131(3):2313.

99. Shahlapour AA, Eslami AH, Eliazian H. Comparative anthelmintic tests in sheep and goats infected with gastro-intestinal nematodes and lungworms in Iran. Trop Ani Health Production. 1970;2(4):223-34.

100. Cavin JC, Krassner SM, Rodriguez E. Plant-derived alkaloids active against Trypanosoma cruzi. J Ethnopharmacol. 1987;19(1):89-94.

101. Muhammad I, Dunbar DC, Khan SI, Tekwani BL, Bedir E, Takamatsu S, et al. Antiparasitic alkaloids from Psychotria klugii. J Nat Prod. 2003;66(7):962-7. 
102. Rosenkranz V, Wink M. Alkaloids induce programmed cell death in bloodstream forms of trypanosomes (Trypanosoma b. brucei). Molecules. 2008;13(10):2462-73.

103. Bahmani M, Abbasi N, Hosseini M, Rafieian-Kopaei M. Concise review: Medicinal plants are effective against leishmaniasis. Biomed Research Therapy. 2017;4(11):1775-84.

104. Han $Y$, Mesplède $T$. Investigational drugs for the treatment of Zika virus infection: A preclinical and clinical update. Expert Opinion Investigational Drugs. 2018;27(12):951-62.

105. Deng L, Dai P, Ciro A, Smee DF, Djaballah H, Shuman S. Identification of novel antipoxviral agents: Mitoxantrone inhibits vaccinia virus replication by blocking virion assembly. J Virology. 2007;81(24):13392-402.

106. Yin LJS, Chen KC, Wu KX, Mah-Lee Ng M, Hann CJJ. Antiviral activity of emetine dihydrochloride against dengue virus infection. J Antivir Antiretrovir 2009;1(1):062-71.

107. Valadão A, Abreu C, Dias J, Arantes P, Verli H, Tanuri A, et al. Natural plant alkaloid (emetine) inhibits HIV-1 replication by interfering with reverse transcriptase activity. Molecules. 2015;20(6):11474-89.

108. Mukhopadhyay R, Roy S, Venkatadri R, Su YP, Ye W, Barnaeva E, et al. Efficacy and mechanism of action of low dose emetine against human cytomegalovirus. PLoS Pathogens. 2016;12(6):e1005717.

109. Mercola D, Welsh J. From mRNA to tumor suppressor. Nature Genetics. 2004;36(9):937.

110. Huusko P, Ponciano-Jackson D, Wolf M, Kiefer JA, Azorsa DO, Tuzmen S, et al. Nonsense-mediated decay microarray analysis identifies mutations of EPHB2 in human prostate cancer. Nature Genetics. 2004;36(9):979.
111. Moyer DL, Thompson RS, Berger I. Anti-implantation action of a Medicated Intrauterine Delivery System (MIDS). Contraception. 1977;16(1):39-49.

112. Mehrotra PK, Kitchlu S, Dwivedi A, Agnihotri PK, Srivastava S, Roy R, et al. Emetine ditartrate: A possible lead for emergency contraception. Contraception. 2004;69(5):379-87.

113. Hopf NJ, Goebel HH. Experimental emetine myopathy: Enzyme histochemical, electron microscopic and immunomorphological studies. Acta Neuropathologica. 1993;85(4):414-8.

114. Pan SJ, Combs AB. Effects of pharmacological interventions on emetine cardiotoxicity in isolated perfused rat hearts. Toxicology. 1995;97(1-3):93104.

115. Keiser MJ, Roth BL, Armbruster BN, Ernsberger P, Irwin JJ, Shoichet BK Relating protein pharmacology by ligand chemistry. Nature Biotechnology. 2007;25(2):197-206.

116. Maddison JE, Page SW, Church DB. Editors. Small animal clinical pharmacology. Elsevier Health Sci. 2008.

117. Zhou YD, Kim YP, Mohammed KA, Jones DK, Muhammad I, Dunbar DC et al. Terpenoid tetrahydroisoquinoline alkaloids emetine, klugine and isocephaeline inhibit the activation of hypoxia-inducible factor-1 in breast tumor cells. J Nat Prod. 2005;68(6):947-50.

118. Ma JK, Chikwamba R, Sparrow P, Fischer R, Mahoney R, Twyman RM. Plantderived pharmaceuticals-the road forward. Trends PI Sci. 2005;10(12):580-5.

119. Weniger B. Interest and limitation of a global ethnopharmacological survey. J Ethnopharmacol. 1991;32(1-3):37-41.

Cite this article: Mondal S, Moktan S. A Paradoxically Significant Medicinal Plant Carapichea ipecacuanha: A Review. Indian J of Pharmaceutical Education and Research. 2020;54(2s):s56-s66. 